\title{
ПЕДАГОГІЧНИЙ ПІДХІД ДО ФОРМУВАННЯ СОЦІАЛЬНО-ЕТИЧНИХ ЦІННОСТЕЙ У ЗДОБУВАЧІВ ВИЩОЇ ОСІТИ
}

\author{
Сікалюк А. I. \\ кандидат педагогічних наук, дочент, \\ дочент кафедри іноземних мов професійного спрямування \\ Національний університет «Чернігівська політехніка» \\ вул. Шевченка, 95, Чернігів, Украӥна \\ orcid.org/0000-0002-6681-271X \\ angelasikaliuk@gmail.com \\ Пермінова В. А. \\ кандидат педагогічних наук, доцент, \\ дочент кафедри іноземних мов професійного спрямування \\ Національний університет «Чернігівська політехніка» \\ вул. Шевченка, 95, Чернігів, Украӥна \\ orcid.org/0000-0002-5082-6308 \\ vladaperminova@gmail.com
}

\begin{abstract}
Ключові слова: особистісні якості, взаємодія, етика, мораль, професійні функиії, майбутній менеджер, рефлексія.
\end{abstract}

У статті висвітлено педагогічний підхід до процесу формування соціальноетичних цінностей у здобувачів вищої освіти, зокрема менеджерів. Обгрунтовано сутність i структуру соціально-етичних цінностей як особистісних якостей майбутніх фахівців економічних спеціальностей. Під впливом цілеспрямованої взаємодії викладача та студента вищого навчального закладу об'єктивні, гуманістичні, загальнолюдські етичні цінності виступають у ролі предмета пізнання та переживання їх як потреб, що спонукають до реалізації цих цінностей у житті. Соціально-етичні цінності мають своє поле в прояві професійно-етичних цінностей, вони відображають систему та характер суспільних відносин. У практиці вони проявляються в поведінці особистості, залежать від професійних функцій і конкретних соціальних ролей. Визначено професійні функції менеджера, які допомагають фахівцю зрозуміти суть розподілу та координації різних видів праці, необхідність проєктування цілей і шляхів їх досягнення, стимулювання, мотивації на досягнення успіху у позитивно спрямованій взаємодії всіх учасників процесу, аналіз, контроль і корекція вчинків та уміння реалізовувати стратегічний план дій, які у сукупності впливають на прийняття рішень і поведінку виконавців: теоретичні, економічні, політичні, соціальні, етичні, естетичні, релігійні. У результаті проведеного пілотного дослідження було виявлено змістову характеристику складників процесу формування соціально-етичних цінностей майбутніх фахівців. Для напряму підготовки «Менеджмент» загалом окреслено окремі соціально-етичні цінності, які реалізуються в практичній діяльності в різних ситуаціях: цілеспрямованість під час проєктування мети та завдань діяльності; соціальна відповідальність за результати власної діяльності та діяльності партнерів чи підлеглих; взаємодія (співпраця) як прояв позитивних дій з метою поліпшення якості результатів; справедливість у вирішенні професійних проблем; толерантність (повага) у вирішенні професійних завдань і розподілі функціоналу учасників. Доведено, щорефлексія є своєрідним умінням студента здійснювати самооцінку, самоаналіз, самокорекцію власної поведінки, власної діяльності. При цьому зазначено, що саме професійна рефлексія передбачає усвідомлення особистістю себе як носія певних професійних соціальноетичних цінностей, які проявляються як відображення стандартизованої професійної поведінки, зумовленої конкретною ситуацією. 


\title{
PEDAGOGICAL APPROACH TO THE FORMATION OF SOCIO-ETHICAL VALUES OF APPLICANTS FOR HIGER EDUCATION
}

\author{
Sikaliuk A. I. \\ Candidate of Pedagogical Sciences, Associate Professor, \\ Associate Professor at the Department of Foreign Languages for Specific Purposes \\ Chernihiv Polytechnic National University \\ Shevchenko str., 95, Chernihiv, Ukraine \\ orcid.org/0000-0002-6681-271X \\ angelasikaliuk@gmail.com \\ Perminova V. A. \\ Candidate of Pedagogical Sciences, Associate Professor, \\ Associate Professor at the Department of Foreign Languages for Specific Purposes \\ Chernihiv Polytechnic National University \\ Shevchenko str., 95, Chernihiv, Ukraine \\ orcid.org/0000-0002-5082-6308 \\ vladaperminova@gmail.com
}

Key words: personal qualities, interaction, ethics, morality, professional functions, future manager, reflection.
The article highlights the pedagogical approach to the process of formation of socio-ethical values in higher education, in particular managers. The essence and structure of social and ethical values as personal qualities of future specialists of economic specialties have been substantiated. Under the influence of purposeful interaction of a teacher and a student of a higher educational institution, objective, humanistic, universal ethical values act as a subject of knowledge and experience them as needs that motivate the realization of these values in life. Socio-ethical values have their field in the manifestation of professional and ethical values; they reflect the system and nature of social relations. In practice, they are manifested in the behavior of the individual, depended on professional functions and specific social roles. The professional functions of the manager have been defined, which help the specialist to understand the essence of distribution and coordination of different types of work, the need to design goals and ways to achieve them, stimulate, motivate to succeed in positive interaction of all participants, analysis, control and correction of actions and ability to implement strategic plan, actions which together affect the decision-making and behavior of performers: theoretical, economic, political, social, ethical, aesthetic, religious. As a result of the conducted pilot research the semantic characteristic of components of formation process of social and ethical values of future experts has been revealed. For the direction of specialty "Management" in general outlined certain socio-ethical values that are implemented in practice in different situations: purposefulness in designing the goals and objectives of the activity; social responsibility for the results of their own activities and the activities of partners or subordinates; interaction (cooperation) as a manifestation of positive actions in order to improve the quality of results; justice in solving professional problems; tolerance (respect) in solving professional tasks and the distribution of the functionality of the participants. It has been proved that reflection is a kind of student's ability to carry out self-assessment, self-analysis, self-correction of their own behavior, their own activities. It has been noted that it is professional reflection involves the realization of the individual as a carrier of certain professional socio-ethical values, which are manifested as a reflection of standardized professional behavior due to a particular situation. 
Постановка проблеми. Одним 3 основних шляхів ефективного розв'язання завдань підготовки здобувачів вищої освіти освітньо-кваліфікаційного рівня «бакалавр» $є$ їх переорієнтація на поєднання якісно нового змісту та форм у соціально-виховному процесі. Зокрема, це стосується розвитку соціально-етичних якостей особистості відповідно до професійних якостей майбутнього фахівця економічної сфери: маркетолога, аудитора, економіста, бухгалтера, менеджера економічної сфери, банківського співробітника та ін.

Педагогічні умови та шляхи формування соціально-етичних цінностей у студентів вищих навчальних закладів розкрито у дисертаційних дослідженнях А. Агаркової, І. Горностаєвої, В. Діуліної, Т. Логвиновської, Л. Олексюк, С. Хлєстової, В. Черевко та ін.; особливості студентської молоді як своєрідної соціально-демографічної спільноти розглядаються 3 різних позицій у працях Н. Борбич, А. Брушлинського, М. Головатого, В. Дзюби, Г. Кардаш, О. Михайлова, О. Научителя, А. Орлова, Д. Пащенка та ін.

Сучасна система підготовки здобувачів вищої освіти нині в основному спрямована на посилення змісту у фаховому плані, що певною мірою виправдано. Проте практика засвідчує, що назріла необхідність звернути увагу і на інший бік підготовки здобувачів вищої освіти - формування у них особистісних якостей. Такими незаперечними якісними утвореннями особистості студентів можуть бути соціально-етичні цінності.

Актуальність проблеми формування соціально-етичних цінностей у здобувачів вищої освіти зумовлена їх віковими особливостями, наявністю умов для закладання основ соціально-етичної поведінки у зв'язку з активним формуванням особистісних установок, стереотипів поведінки, світогляду, що дає можливість формувати загальнолюдські та професійні цінності. Водночас поняття «соціально-етичні цінності» через свою багатоаспектність натепер у педагогіці не сформульовано і не знайшло свого місця у позанавчальній роботі, що і зумовлює появу у виховній діяльності сучасної вищої школи низки суперечностей між потребами суспільства в підвищенні рівня соціально-етичної культури фахівців різних спеціальностей і недостатнім використанням педагогічного потенціалу у формуванні соціально-етичних цінностей у вищій школі.

Мета статті - дослідити педагогічний підхід до процесу формування соціально-етичних цінностей у здобувачів вищої освіти та обгрунтувати сутність і структуру соціально-етичних цінностей як особистісних якостей майбутніх фахівців економічних спеціальностей, зокрема менеджерів.

Виклад основного матеріалу дослідження. Ми вважаємо за доцільне звернути увагу на педа- гогічний підхід до проблеми формування цінностей, зокрема соціально-етичних цінностей, який відображає взаємодію особистості із соціумом, світом, із самим собою з метою прояву потенційних цінностей і як особистості, і як майбутнього фахівця. Під впливом цілеспрямованої взаємодії викладача та студента вищого навчального закладу об'єктивні, гуманістичні, загальнолюдські етичні цінності виступають у ролі предмета пізнання та переживання їх як потреб, що спонукають до реалізації цих цінностей у житті. Лише у такому разі ті чи інші соціально-етичні норми можуть виступати регулятором поведінки особистості студента.

Соціально-етичні цінності мають своє поле в прояві професійно-етичних цінностей, вони відображають систему та характер суспільних відносин. У практиці вони проявляються в поведінці особистості, залежать від професійних функцій i конкретних соціальних ролей.

Так, загальні функції менеджера, на думку В. Черевко, базуються на його знаннях: організаційних, управлінських і комунікативних. Загальні функції майбутнього менеджера окреслили також американські вчені М. Мескон, М. Альберт, Ф. Хедоурі: планування, організаційні, мотивація, контрольні [2, с. 23]. На нашу думку, найбільш повно окреслив професійні функції менеджера А. Карпов: цілепокладання, прогнозування, організація, мотивування, прийняття рішень, контроль, корекція та комунікація [1].

Зазначені вище професійні функції менеджера допомагають фахівцю зрозуміти суть розподілу та координації різних видів праці, необхідність проєктування цілей $i$ шляхів їх досягнення, стимулювання, мотивації на досягнення успіху у позитивно спрямованій взаємодії всіх учасників процесу, аналіз, контроль і корекція вчинків та уміння реалізовувати стратегічний план дій, які у сукупності впливають на прийняття рішень і поведінку виконавців: 1) теоретичні; 2) економічні; 3) політичні; 4) соціальні; 5) етичні; 6) естетичні; 7) релігійні. Такі напрями цінностей потребують від управлінців вибору мети управління та цілей, які можуть поєднувати як загальноетичні, так і професійно-етичні норми.

Звідси ми виходимо на визначення робочого варіанту змісту основного поняття «сформованість соціально-етичних цінностей у менеджерів економічної сфери», яке ми розуміємо як результат засвоєння особистістю через ціннісно-раціональну діяльність та функціонал менеджера економічної сфери етичних цінностей, необхідних для виконання соціальних ролей такого фахівця, в яких відображено складники соціально-етичних цінностей (цілеспрямованість, соціальна відповідальність, взаємодія (співпраця), справедливість, толерантність (повага). 
На основі аналізу різних класифікацій цінностей ми дійшли висновку, що до складу ключових цінностей входить соціально-етична цінність, яка включає:

- схильність до етичних цінностей, здатність приймати на їх основі рішення в конкретних ситуаціях, володіння етикою трудових і громадянських взаємин (В. Андрієвська, М. Боришевський, В. Караковський, О. Левцун та ін.);

- наявність особистісних і професійних цінностей (О. Михайлов, О. Олексюк, Н. Побірченко, С. Савченко та ін.);

- уміння брати на себе соціальні й етичні обов'язки (I. Селезньова, І. Шевченко, К. Шарова та ін.).

Ми розглядаємо поняття «етика» ширше ніж поняття «мораль», оскільки філософи сприймають iї як науку про мораль, принципи, норми в суспільстві [4]. Проте, пов'язуючи соціальний характер поведінки менеджера, ми можемо говорити про його професійну етику, яка вивчає не лише загальні моральні принципи та норми в різних видах управлінської діяльності, а й сукупність правил поведінки конкретної соціальної групи, які забезпечують моральний характер взаємин, зумовлених чи пов'язаних з професійною діяльністю [5].

Виходячи 3 характеристики соціально-етичної цінності як інтегрованої характеристики особистості майбутнього фахівця, ми вважали за доцільне визначити структурні елементи соціально-етичної цінності: знання, мотиви, переконання, поведінкові навички (позиціі), особистісні якості та установки. Узагальнюючи різні точки зору на зміст і структуру соціально-етичних цінностей, ми окреслили складники структури: теоретичний, практичний, індивідуальний.

У результаті проведеного пілотного дослідження було виявлено змістову характеристику складників процесу формування соціально-етичних цінностей майбутніх фахівців. При цьому домінуючим структурним складником ми визначили теоретичний складник, що виступає базовим у формуванні знань соціально-етичних основ, необхідних у професійній діяльності. Для напряму підготовки «Менеджмент» і окремих спеціалізацій загалом можна окреслити такі соціально-етичні цінності, які реалізуються в практичній діяльності в різних ситуаціях, як:

- цілеспрямованість під час проєктування мети та завдань діяльності;

- соціальна відповідальність за результати власної діяльності та діяльності партнерів чи підлеглих;

- взаємодія (співпраця) як прояв позитивних дій з метою поліпшення якості результатів;

- справедливість у вирішенні професійних проблем;
- толерантність (повага) у вирішенні професійних завдань і розподілі функціоналу учасників.

На жаль, введення нової спеціальності (а саме менеджменту) в Україні не завжди сприяє виробленню відповідного професійно-етичного кодексу, такий аспект ще не простежується в підручниках і посібниках для студентів вищої школи.

Розкриваючи зміст практичного складника у формуванні соціально-етичних цінностей, слід зробити акцент на необхідності формування відповідних умінь і навичок, які б були адекватними до норм і вимог соціальної етики професіонала. Соціально-етичні цінності у такому разі диктують сукупність правил поведінки, які регулюють прояв людських взаємин 3 оточенням (форми звертання, привітання, стиль поведінки та мовлення тощо). Соціально-етичні цінності - це ще й відображення внутрішніх установок і цілей особистості в професійній діяльності. Дотримування соціально значущих установок і етичних норм у сукупності забезпечують взаєморозуміння суб'єктів партнерства, підвищують рівень успішності у вирішенні службових проблем і результатів спільних дій, а також свідчать про певний рівень професійної культури.

Можна говорити про три етапи (кроки) у формуванні соціально-етичних цінностей: від знань до умінь, від умінь до навичок. Останнє засвідчує автоматизований їх прояв у професійних діях, при цьому говорити про їх повноцінний прояв можна лише у разі наявності певного професійного досвіду, яким студенти оволодівають під час включення у позанавчальну виховну діяльність.

Третій складник у структурі формування соціально-етичних цінностей - індивідуальний. Він передбачає прояв рефлексивних умінь, мотиваційно-ціннісних орієнтацій, соціально вольових якостей [5].

Без сумніву, рефлексія є своєрідним умінням студента здійснювати самооцінку, самоаналіз, самокорекцію власної поведінки, власної діяльності [3]. При цьому слід зазначити, що саме професійна рефлексія передбачає усвідомлення особистістю себе як носія певних професійних соціально-етичних цінностей, які проявляються як відображення стандартизованої професійної поведінки, зумовленої конкретною ситуацією.

Підтримуючи викладені позиції та взявши до уваги інформацію про необхідність формування у студентів соціально-етичних складників, вважаємо за доцільне сформувати власну позицію щодо трактування сутності поняття «соціально-етичні цінності», при цьому на двох рівнях. У широкому розумінні поняття «соціально-етичні цінності» можна розглядати як один із факторів, що відображає взаємозв'язок людини та суспільства. Тому їх слід сприймати як інтегративну одиницю, яка трансформує етичний аспект взаємодії людини, соціальних 
інституцій і спільноти. У вузькому значенні соціально-етичні цінності - це сукупність особистісних i соціально значущих якостей, які відображають цілі, характер дій і поведінки особистості, що дозволяє говорити про соціально-етичні цінності як про інтегративну якість особистості, яка включає систему соціальних знань, оціночних суджень, соціально-етичних установок, вчинків, спрямованих на прояв етичної поведінки та взаємодію 3 представниками різних інституцій, на ініціативність і самостійність у прийнятті рішень, на гармонізацію ділових та особистісних якостей студентів.

Висновки. Таким чином, можна сказати, що:

- загальнолюдські етичні цінності розглядаються у сучасній вітчизняній і зарубіжній педагогіці як основа виховання й освіти молоді незалежно від того, в якій країні, в якій національній школі чи вищій школі воно здійснюється;

- соціально-етичні цінності ми розглядаємо як сукупність особистісних і соціально значущих якостей, які відображають цілі, характер дій і поведінки особистості;

- засвоєння таких понять відбувається в процесі інтеріоризації загальнолюдських цінностей, який завершується формуванням ціннісних орієнтацій особистості - спрямованості особистості на соціально-етичну діяльність у певній сфері;
- інтеріоризація загальнолюдських етичних цінностей $є$ процесом поступового перетворення об'єктної орієнтації особистості (уявлення про загальнолюдські цінності) в іiї суб'єктну орієнтацію: готовність діяти згідно зі сформованими уявленнями про соціально-етичні цінності в конкретній сфері діяльності;

- орієнтація особистості на соціально-етичні цінності може бути сформована у процесі професійної підготовки у позанавчальній виховній діяльності з використанням адекватного змісту, форм і методів.

Отже, різні наукові підходи до процесу формування, суті та складників соціально-етичних цінностей стали науковим підгрунтям для подальшого розгортання напрямів соціально-виховного процесу у вищій школі, пошуку змісту, форм і методів, які можуть впливати на якість процесу формування соціально-етичних цінностей у студентів економічних спеціальностей у позанавчальній виховній діяльності.

Дослідження проблеми формування соціально-етичних цінностей студентів вищої школи не вичерпує всіх іiі аспектів. У перспективі необхідно зосередити увагу на розробці спеціальних програм і методик формування соціально-етичних цінностей для викладачів-кураторів.

\section{ЛITЕРАТУРА}

1. Карпов А.В. Психология менеджмента. Москва : Гардарики, 2015. 584 с.

2. Мескон М., Альберт М., Хедоури Ф. Основы менеджмента. Москва : Дело, 2002. 702 с.

3. Словник-довідник для соціальних працівників та соціальних педагогів. Київ : Аспект, 2000. 260 с.

4. Чмут Т.К., Чайка Л.Г. Етика ділового спілкування. Київ : Знання, 2007. 230 с.

5. Шевнюк О.Л. Культурологія. Київ : Знання-Прес, 2004. 353 с.

6. Ширшов В.П. Философия становления личности: ценностный аспект. Магистр. 1997. С. 91-93.

\section{REFERENCES}

1. Karpov, A.V. (2015). Psyhologiya menedzhmenta [Psychology of management]. Moscow: Gardariki. P. 584 [in Russian].

2. Meskon, M., Albert, M., Hedouri, F. (2002). Osnovy menedzhmenta [The basics of management]. Moscow: Delo. P. 702 [in Russian].

3. Slovnyk-dovidnyk dlya sotsialnyh pratsivnykiv ta sotsialnyh pedagogiv (2000) [Dictionary-reference book for social workers and social educators]. Kyiv: Aspekt. P. 260 [in Ukrainian].

4. Chmut, T.K., Chajka, L.G. (2007). Etyka dilovogo spilkuvannya [Ethics of business communication]. Kyiv: Znannya. P. 230 [in Ukrainian].

5. Shevniuk, O.L. (2004). Kulturologiya [Culturology]. Kyiv: Znannya-Press. P. 353 [in Ukrainian].

6. Shyrshov, V.P. (1997). Filosofiya stanovleniya lichnosti: tsenostnyi aspect [Philosophy of personality formation: value aspect]. Master. P. 91-93 [in Russian]. 